\title{
Assessment of the Current State of Meliorative Regime of Natural and Anthropogenic Complexes in Kalmykia
}

\author{
Mutul Maksimovich Okonov and Elvira Batyrevna Dedova
}

\begin{abstract}
${ }^{1}$ Federal State Budgetary Educational Institution of Higher Professional Education, Kalmyk State University, 1, Pushkin Street, Elista, Russia, 358000

${ }^{2}$ Federal State Budgetary Scientific Institution, The All-Russian Research Institute of Hydraulic Engineering and Amelioration n.a. A. N. Kostyakov, (VNIIGIM), 44, Bolshaya Academicheskaya str., Moscow, Russia 127750
\end{abstract}

DOI: http://dx.doi.org/10.13005/bbra/1922

(Received: 01 October 2015; accepted: 19 November 2015)

The article shows the results of long-term studies aimed at assessing the formation of ameliorative regime of natural-anthropogenic complexes in Kalmykia. Initial parameters have been presented for models of forming the water-salt regime of the irrigated agricultural landscapes with their comprehensive amelioration in semi-desert and desert areas of Kalmykia. The influence of water-salt regime of soils on the productivity of saltmarsh bluegrass and alfalfa has been studied, and the threshold of salt tolerance for these crops has been defined. The technology of recovering re-salinized irrigated land with the use of reclaimer crops has been developed, which makes it possible not only to rehabilitate the soils that are adverse due to re-salinization, but to obtain extra quality forage as well.

Key words: Comprehensive melioration, ameliorative regime, water-and-salt balance, phyto-ameliorants, salt tolerance, yield.

The modern concepts of adaptivelandscape systems of land use and ecosystemfriendly water use, which are based on comprehensive amelioration, make it possible to proceed to creating sustainable and highly productive natural and anthropogenic ecosystems of various levels.

Forming a favorable ameliorative regime of a territory is performed based on analyzing natural conditions and forecast of their changes as a result of anthropogenic impact. An ameliorative regime is a set of requirements to controlled factors of soil formation and the environment, which ensure further radical

\footnotetext{
* To whom all correspondence should be addressed.
}

improvement of soil fertility and obtaining predefined yield of major agricultural crops $^{1-5}$. An ameliorative regime can be favorable if, as a result of proper irrigation and implementation of all activities in the farming system, preservation and increase in soil fertility are observed, and unfavorable - in case of soil salinization, solonization and marsh formation. One of the main indicators of an ameliorative regime of soils in different climatic zones is the level of mineralized groundwater and associated intensity and direction of moisture-, salt-, and heat transfer-10 ${ }^{6}$. For this purpose, in assessing the current state of the ameliorative regime, many-year monitoring of the ameliorative state of the soil on the irrigated lands in the irrigation systems of Kalmykia is of particular importance. 
Methods

The Republic of Kalmykia is situated in the Southeast of the European part of the Russian Federation. Its territory (74.7 thousand $\mathrm{km}^{2}$ ) is characterized by sharply continental arid climate. Out of the total area of the agricultural land, about $80 \%$ is grassland, $18 \%$ is arable land, and $2 \%$ are hayfields. Historically, agriculture in Kalmykia is focused on livestock breeding (sheep and beef cattle). The natural agricultural zones of the Republic of Kalmykia are presented by[1]: the western steppe - the areas located on the spurs of the Stavropol upland and the Kumo-Manych depression; the central steppe - the areas of the Yergeni upland and Primanych lands; the semiarid north - the northern part of the Caspian lowland (the Northern Sarpin plain, Priyergeni plain); and the south-eastern desert and semi-desert - the southern part of the Caspian lowland (Black Land). Extreme climatic conditions (Table 1) and low natural fertility of soils caused by their significant complexity, salinity and alkalinity do not make it possible to effectively perform agricultural activities without a complex of special ameliorative measures, the main of which are irrigation and chemical amelioration.

The scientific research is based on classic doctrines about soil, soil formation processes, soil fertility, salinization by V.B. Dokuchaev, V. I. Vernadsky, V. R. Williams, A. N. Kostyakov, V. A. Kovda, G. B. Rozanov; works for preventing the processes of desertification and development of degraded soils on the principles of ecological balance of hydro-ameliorative, forest improvement $[2,8,11,12,13]$, agro-ameliorative and other actions (B. A. Keller, E. S. Pavlovsky, M. P. Petrov, N. G. Kharin, I. S. Zonn, G. S. Kust, B. M. Kizyaev, I. P. Kruzhilin, V. I. Petrov, K. N. Kulik, L. V. Kireicheva, V.V. Borodychev, E. B. Gabunshina, et al.); and desalinizing and de-alkalizing ability of plants (B. P. Strogonov, P. A. Genkel, G. V. Udovenko, P. P. Beguchev, B. A. Zymovets, Z. S. Shamsutdinov, A. O. Lachko, L. V. Rudnev) $[14,15,16]$. In assessing formation of ameliorative regime for adaptive landscape systems of land use, the stock materials for years 1983...2014 obtained from the soil analytical laboratory of the Kalmyk branch of VNIIGiM n.a. A. N. Kostyakov, and the materials from ameliorative land inventories for the Republic of Kalmykia were used.
The results of the experiments were processed using correlation, regression, and dispersion analysis according to the method of $\mathrm{B}$. A. Dospekhov (1985), using the STATISTICA 6.0 software and Microsoft Excel XP spreadsheet editor.

\section{RESULTS}

In order to create an optimal reclamation regime on the irrigated lands, it is necessary first of all to maintain the water-salt regime in the root layer of soil within the prescribed parameters. Many years of monitoring soil and land conditions on the irrigation systems of Kalmykia [17, 18, 19, 20 , 21] made it possible to establish the regularities of forming the water-salt regime of irrigated soils in various soil-climatic zones, ensuring their optimization and allowable groundwater level, aimed at maintaining and preserving soil fertility and sustainable functioning of natural ecosystems (Tab. 2).

The steppe zone. The main part of the irrigated land in this area is ordinary carbonate low-humus, and dark brown medium loamy or nonsolonetzic or weakly solonetzic black earth. In this area, where crop production is mainly concentrated, the requirements for the ameliorative regime are more stringent. Irrigated land covers 4.5 thousand ha (2.4\% of the arable land area), and is located in the area of the Right-Egorlyk irrigation system, the main water source of which is the Kuban River (water salinization 0.3-0.5 g/l).

Beside the water from the Kuban River, in the area of Right-Egorlyk irrigation/water distribution system (REIWDS), the mixed (Kuban + drainage) water from the Gorodovikovsk water reservoir and the water from local runoff (the Egorlyk River and ponds) with the mineralization of 2-4 g/l are used. The prevailing method of irrigation is overhead irrigation. The main disadvantage and adversity of the REIWDS is the presence of significant unproductive loss of water, since all channels are arranged in the earth channel, which results in increased lateral and vertical filtering (system efficiency coefficient is 0.54-0.66) and, as a consequence, rising groundwater, secondary salinization and gleization of loamy soils, i.e. in overall deterioration of the ameliorative state of the territory. The limits of 
Table 1. Characteristic of natural and climatic conditions of Kalmykia

\begin{tabular}{|c|c|c|c|c|}
\hline \multirow[t]{2}{*}{ Indicators } & \multicolumn{4}{|c|}{ Natural and agricultural zones } \\
\hline & Steppe & Dry steppe & Semi-desert & Desert and semi-desert \\
\hline Area, million ha & 0.24 & 2.18 & 1.73 & 2.24 \\
\hline Average temperature, ${ }^{\circ} \mathrm{C}$ : & & & & \\
\hline the coldest month & $-4,-5$ & $-6,-7$ & $-8,-9$ & $-6,-8$ \\
\hline the warmest month & $23.5 \ldots 24.0$ & $24.5 \ldots 25.5$ & $24.7 \ldots 25.5$ & $25.0 \ldots 26.0$ \\
\hline Sum of $\mathrm{t}>10^{\circ} !$ & $3,292 \ldots 3,380$ & $3,362 \ldots 3,400$ & $3,329 \ldots 3,523$ & $3,474 \ldots 3,650$ \\
\hline Frost-free period, days & $175 \ldots 180$ & $160 \ldots 185$ & $143 \ldots 190$ & $175 \ldots 200$ \\
\hline Precipitation (P), mm/year & $403 \ldots 423$ & $315 \ldots 400$ & $243 \ldots 278$ & $209 \ldots 259$ \\
\hline $\begin{array}{l}\text { Number of days with hot dry } \\
\text { winds, days }\end{array}$ & $4 . .6$ & $100 \ldots 104$ & $100 \ldots 119$ & $119 \ldots 124$ \\
\hline Precipitation for period IV-IX, mm & $250 \ldots 270$ & $186 \ldots 220$ & $147 \ldots 174$ & $114 \ldots 147$ \\
\hline Rate of evaporation (E0), mm/year & $915 \ldots 970$ & $1,000 \ldots 1,100$ & $1,100 \ldots 1,180$ & $1,036 \ldots 1,200$ \\
\hline Annual rainfall factor $(\mathrm{Rf}=\mathrm{P} / \mathrm{E} 0)$ & 0.44 & $0.32 \ldots 0.36$ & $0.22 \ldots 0.26$ & $0.20 \ldots 0.22$ \\
\hline Degree of aridity & weakly arid & medium arid & highly arid & extremely arid \\
\hline Aridity (moisturization) coefficient & $0.46 \ldots 0.60$ & $0.31 \ldots 0.45$ & $0.16 \ldots 0.30$ & $0.11 \ldots 0.15$ \\
\hline
\end{tabular}

Table 2. Values of the main indicators of the ameliorative regime for irrigated soils by natural zones of Kalmykia

\section{Indicators}

of the ameliorative regime
Natural and agricultural zones

\begin{tabular}{lll}
\hline dry steppe & \multicolumn{2}{c}{ semi-desert } \\
\cline { 2 - 3 } chestnut, & $\begin{array}{l}\text { light brown } \\
\text { light chestnut }\end{array}$ & alkaline, brown - semi desert \\
solonetzic and & semi-desert & their complexes \\
their complexes & medium loamy & with alkaline-desert \\
with chestnut & alkaline & soils \\
alkaline earth & & \\
\end{tabular}

Water regime: the limits of regulating moisture content in the root zone, in shares of the field moisture capacity

the limits of regulating the level of groundwater intensity of percolative regime of soils

\section{Salt regime:}

$\mathrm{pH}$

content of easily soluble salts $(0-40 \mathrm{~cm}), \%$ absorption capacity, mg-eq./100g of soil in soil adsorption complex,\% $\mathrm{Na}$

-in the solution of $\mathrm{Na} /$ " $\mathrm{Ca}$;

- Na/"'Mg;

mineralization of irrigation water, g/l

Nutrient status:

content of humus, \%

$\mathrm{P}_{2} \mathrm{O}_{5}$, mg-eq./100g of soil

${ }_{2}$, mg-eq./100g of soil
$0.70 \ldots 0.75$

$3 . . .5$

$\leq(0.1 \ldots 0.15)$

$7.0 \ldots 8.0$

$0.1 \ldots 0.4$

$10 . .20$

$<3$

$\leq 0.4 \ldots 0.6$

$\leq 0.5 \ldots 0.7$

$1.0 \ldots 2.0(4.0)$

$3 . . .4$

$>4$

$30 . .60$

46...50

20...30
$0.75 \ldots 0.80$

$>3$

$\leq(0.1 \ldots 0.15)$

$0.75 \ldots 0.90$

$>3$

$\leq(0.1 \ldots 0.20)$

$7.0 \ldots 8.0 \quad 7.5 \ldots 8.2$

$0.2 \ldots 0.4 \quad 0.4 \ldots 0.6$

$10 \ldots 15 \quad 10 \ldots 15$

$<5 \quad 5 \ldots 10$

$\leq 1.0(1.5) \quad<1.0$

$\leq 01.0(1.8) \leq 1.0$

$0.3 \ldots 0.7$ (4...6) $0.5 \ldots 1.8(3 \ldots 5)$

$2 . . .3$

$4 . .66$

$1.8 \ldots 2.5$

$2 . .5$

$20 . .40$

$20 \ldots 60$
Air regime:

porosity, \%
Thermal regime:

soil temperature during the growing season, ${ }^{\circ} \mathrm{C}$

$44 \ldots 48$

$44 \ldots . .48$

$20 . .30$

$20 \ldots 30$ 
Table 3. Agricultural amelioration characteristics for creating models of water-salt regime control on ameliorated lands of Kalmykia

Name ofparameters

1

Meteorological:

- rainfall per year, mm

- sum of active temperatures, $\mathrm{C}^{\circ}$

- evaporation, mm

- coefficient of natural watering

Morphological:

- thickness of the plough layer, cm

Agrophysical:

- plough layer bulk density, g/ $\mathrm{cm}^{3}$

- water- stable aggregates $>0.25 \mathrm{~mm}, \%$

- content of the $0.01 \mathrm{~mm}$ fraction, \%

- stabilized infiltration rate, $\mathrm{mm} / \mathrm{min}$

- the lowest saturation capacity,\%

- active porosity, \%

the coefficient of hydrodynamic dispersion

Moisture content, below which roots of plants:

- start extracting water from the soil;

- start extracting water from the top layers of soil;

- start extracting water from the bottom layers of soil;

- are unable to extract water due to high atmospheric requirements;

- are unable to extract water due to low atmospheric requirements;

- impossibility to extract (the wilting point)

Physico- chemical:

- content of humus, \%

- pH salt

- the sum of absorbed alkali, mg- eq./100g of soil

- the ratio of cations in the soil solution, mg- eq./l

$\mathrm{Na} / \mathrm{Ca}$

$\mathrm{Na} / \mathrm{Mg}$

Agrochemical:

- content of water soluble salts, \%

- mobile forms of phosphorus, mg/100g soil;

-mobile forms of potassium, mg/100g soil;

Hydrological and hydrochemical:

- spring reserve of productive moisture, $\mathrm{mm}$ :

in the $0-20 \mathrm{~cm}$ layer

in the $0-100 \mathrm{~cm}$ layer

- ground water table, $\mathrm{m}$

- mineralization of ground water, g/l

- mineralization of irrigation water, g/l

- the limits of regulating moisture content in the root zone, share of the field moisture capacity - intensity of water exchange between soil and groundwater, the share of evaporation

The yield of hay of reclaimer crops, t/ha

- blue cross-breed alfalfa

- coach-grass, the "Solonchak" variety
Soil types

Semi-desert Brown semidesert brown loamy sandy-loam and sandy
Light brown loamy

278
3,330
1,064
0.26

$25 . .30$

1.30

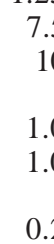

$\begin{array}{ccc}0.2 \ldots 0.4 & 0.4 \ldots 0.6 & 0.4 \ldots 1.2 \\ 4 \ldots 9 & 2 \ldots .5 & 2 \ldots 3 \\ 20 \ldots 40 & 40 \ldots 70 & 25 \ldots 30\end{array}$

$\begin{array}{ccc}40 \ldots 60^{*} & 40 \ldots 50 & 30 \ldots 38 \\ 300 \ldots 700^{*} & 200 \ldots 250 & 200 \ldots 250 \\ & & (250 \ldots 300)^{* *} \\ 1.0 \ldots 2.5 & 1.5 \ldots 3 & 1.7 \ldots 2.5(0.9 \ldots 1.2)^{* * *} \\ 3 \ldots 15 & 10 \ldots 50 & 5 \ldots 20 \\ 0.3 \ldots 0.7 & 1.2 \ldots 1.8 & 1.2 \ldots 2.0 \\ (4 \ldots 6)^{* * * *} & (3 \ldots 4.5)^{* * * *} & \\ 0.70 \ldots 0.90 & 0.70 \ldots 0.90 & 0.70 \ldots 0.90 \\ 0.10 \ldots 0.15 & 0.10 \ldots 0.15 & 0.10 \ldots 0.20 \\ 18 \ldots 20 & 16 \ldots 18 & 14 \ldots 16 \\ 12 \ldots 15 & 10 \ldots 12 & 8 \ldots 10\end{array}$

Note: * - water reserves in rice crop rotations; $* *$ - in brackets, moisture resources in the canal area are shown; ***- in brackets the ground water table in the canal area is shown; ****- mineralization of drainage-discharge water used for watering. 
regulating the moisture content in the soil in the area should be in the range of $65 . . .75 \%$ of the field moisture capacity. The prevailing indicator of ameliorative trouble of lands is re-salinization of soils ( $25 \%$ of the total irrigated area). Another cause of the deterioration of ameliorative condition is the disturbance of ground water, availability of drainage at present being about 35\%.

\section{The dry-steppe zone}

The soil cover is mainly represented by brown and light brown solonetzic soils, and their complexes with solonetzes up to $25 \%$. The main method of irrigation is overhead irrigation, and on salinized soil - surface irrigation methods (along furrows and irrigation bands). The limit of regulating moisture content in the root zone is $70 \ldots 75 \%$ of the field moisture capacity. Mineralization of the irrigation water should not exceed $1 . . .2 \mathrm{~g} / \mathrm{l}$, and the content of toxic salts in soil $-0.2 \ldots . .0 .3 \%$ of its dry weight. On strongly saline soils, it is recommended to perform leaching in combination with the plastering with the dosage of 4-6 t/ha. With that, leaching without drainage is only possible in case of deep (> $5 \mathrm{~m}$ ) groundwater. As a result of soil leaching, the content of watersoluble salts should be not more than $0.3 \ldots 0.4 \%$. Single leaching norms for the dry steppe zone should not exceed $2,000 \mathrm{~m}^{3} / \mathrm{ha}$. After plastering and leaching, deep plowing is made, organic fertilizers (30...50 t/ha) are introduced, and crops with strong root system are planted.

\section{The semi-desert area}

The soil cover is to various degrees represented by solonetzic light-chestnut soils together with solonetzes up to $40-45 \%$, and brown semi-desert soils in combination with saline semidesert soils. The irrigated lands are located in the area of Chernozemelsk (ChIWDS), Sarpinsk (SIWDS) and the Kalmyk-Astrakhan (KAIWDS) irrigation/water distribution systems. Adverse and severe natural and hydrogeological conditions caused by lack of drainage and weak natural drainability of the territory require construction of artificial drainage, the demand for which is $70-80$ $\%$. The prevailing method of irrigation on light chestnut and brown semi-desert medium loamy soils is overhead irrigation, spraying and drip irrigation. This makes it possible to adjust soil humidity in a narrow range with the permissible limits of $75 . . .80 \%$ of the field moisture capacity. On saline soils with salt content of 0.4 to $0.8 \%$, surface irrigation methods are required (along furrows and irrigation bands). On brown semi-desert loamy soils, surface irrigation by checks, bands and furrows is recommended. The limit of adjusting soil humidity is $80 . . .90 \%$ of the field moisture capacity.

The desert and semi-desert zone of the Republic is within the Black Lands soil amelioration area. From ancient times, they have used as distant pastures not only for Kalmykia, but for several neighboring regions as well. With the construction of the Chernozemelsk IWDS, a possibility appeared to irrigate large areas of this natural ameliorative area. The majority of irrigated lands are semi-desert brown medium loamy and sandy loamy soils, weakly humous, subject to resalinization and located in satisfactorily drained territories. The soilforming rocks are light loams and sand clays and even sands, underlain mostly by intercalating strata of clays, loams, sandy loams and sands. Salinization of both underlying and soil-forming rocks is closely connected with the granulometric composition of individual layers. Clayish and loamy layers feature higher degree of salinization, as compared to sandy loamy and sandy soils. Groundwater is confined to the Khvalyn and Khazar sandy sediments at the depth of 5 to $15 \mathrm{~m}$ with quite varying (1.0 to $50.0 \mathrm{~g} / \mathrm{l})$ mainly high salinity $[15,20,21,22]$. The outflow of ground water (drainage conditions) is virtually absent, which in combination with high natural salinity of the aeration zone creates very serious difficulties in development of irrigated agriculture.

The main ways of irrigation are overhead irrigation and drip irrigation, which ensure optimal regime and economical use of water, and surface irrigation along irrigation bands and flooding estuaries. The limits of regulating the moisture content in the soil in this area should be in the range of $70 \ldots 85 \%$ of the field moisture capacity. In this regard, we have developed a conceptual model for increasing the potential of natural resource in degraded agricultural lands by means of comprehensive land amelioration (Fig. 1.).

achieving the minimum active salt exchange in irrigated lands are of paramount importance. In the arid zone from the ecological point of view, the main objectives are improving the quality of surface and irrigation water, depletion 
Table 4. Irrigation regime of phyto-ameliorants of re-salinized irrigated lands in Kalmykia

\begin{tabular}{|c|c|c|c|c|c|c|c|}
\hline \multirow{2}{*}{$\begin{array}{l}\text { Year of } \\
\text { life }\end{array}$} & \multirow{2}{*}{$\begin{array}{l}\text { The yield of } \\
\text { hay, t/ha }\end{array}$} & \multicolumn{3}{|c|}{ Semi-desert zone } & \multicolumn{3}{|c|}{ Desert and semi-desert zone } \\
\hline & & $\begin{array}{c}\text { Irrigation } \\
\text { norm, m³/ha }\end{array}$ & $\begin{array}{l}\text { Number of } \\
\text { irrigatio ns }\end{array}$ & $\begin{array}{c}\text { Irrigation } \\
\text { norm, m³/ha }\end{array}$ & $\begin{array}{c}\text { Irrigation } \\
\text { norm, m³/ha }\end{array}$ & $\begin{array}{l}\text { Number of } \\
\text { irrigations }\end{array}$ & $\begin{array}{l}\text { Irrigation } \\
\text { norm,m³/ha }\end{array}$ \\
\hline \multicolumn{8}{|c|}{ Blue cross-breed alfalfa } \\
\hline $1 \mathrm{st}$ & $3.0 \ldots 7.0$ & $400 \ldots 500$ & $6 . .7$ & $2,600 \ldots 3,250$ & $500 . .600$ & $8 \ldots 9$ & $4,250 \ldots 5,100$ \\
\hline Past & $10.0 \ldots 20.0$ & $400 \ldots 600$ & $8 \ldots 10$ & $3,600 \ldots 5,400$ & $500 \ldots 700$ & $10 \ldots 12$ & $5,500 \ldots 7,700$ \\
\hline \multicolumn{8}{|c|}{ Elongated coach-grass, the "Solonchak" variety } \\
\hline $1 \mathrm{st}$ & $1.5 \ldots 2.5$ & $250 \ldots 300$ & $4 \ldots 5$ & $1,100 \ldots 1,375$ & $300 \ldots 400$ & $5 \ldots 6$ & $1,650 \ldots 2,200$ \\
\hline Past years & $8.0 \ldots 15.0$ & $400 \ldots 500$ & $6 \ldots 7$ & $1.800 \ldots 2.100$ & $500 \ldots 600$ & $7 \ldots 8$ & $3.750 \ldots 4.500$ \\
\hline
\end{tabular}

Table 5. Alfalfa hay yield in the 2nd - 3rd years of life, depending on the content of water soluble salts in the soil $(0-70 \mathrm{~cm}), \mathrm{t} / \mathrm{ha}$

\begin{tabular}{|c|c|c|c|c|c|c|c|c|c|c|}
\hline \multirow{2}{*}{$\begin{array}{l}\text { Rates of introducing } \\
\text { mineral fertilizers, } \\
\text { kg/ha of active } \\
\text { substance }\end{array}$} & \multicolumn{10}{|c|}{ Content of water-soluble salts, \% } \\
\hline & 0.159 & 0.217 & 0.284 & 0.331 & 0.380 & 0.452 & 0.522 & 0.564 & 0.735 & 0.809 \\
\hline without fertilizers & 10.8 & 9.6 & 8.7 & 7.1 & 5.3 & 3.8 & 2.9 & 1.9 & 0.5 & 0.2 \\
\hline $\mathrm{N}_{90} \mathrm{P}_{110}$ & 15.2 & 13.8 & 12.4 & 11.8 & 11.1 & 9.6 & 7.4 & 6.3 & 2.8 & 0.8 \\
\hline $\mathrm{N}_{120} \mathrm{P}_{150}$ & 17.4 & 16.8 & 15.3 & 14.1 & 13.6 & 12.4 & 11.7 & 10.4 & 3.2 & 1.1 \\
\hline
\end{tabular}

of the river flow, preventing resalinization, removing the areas with high geological reserves of salts from amelioration, and reducing mineralization and the volume of drainage flow ${ }^{16}$, $18,19,22$.

In the desert area, the basis for amelioration activities is minimizing the zone of active salt exchange, discharge of mineralized drainage water (over $2 \mathrm{~g} / \mathrm{l}$ ), rising highly mineralized solutions into the top soil horizons, preventing alternate concentration and di8ssolution, i.e. resalinization and leaching ${ }^{4,16,17}$.

The environmental requirements for salt regime of irrigated soils include limitations for the following parameters ${ }^{2,4,13,19,20}$ : mineralization and chemical composition of soil solutions $(\mathrm{Cl}, \mathrm{Na}, \mathrm{Mg}$, $\mathrm{Ca}, \mathrm{SO}_{4}, \mathrm{CO}_{3}$ ); composition of absorbed alkali (Na, $\mathrm{Ca}, \mathrm{Mg})$; environment reaction $(\mathrm{pH})$; degree of saturation with alkali. Selecting source data for creating a model of water-salt regime control in irrigated lands of the arid zone was determined in accordance with the following tasks: developing measures for restoring and preventing degradation of re-salinized lands with the use of phytoameliorant crops; creating favorable water-salt and nutrient regimes for agricultural crops. The list of the initial data is shown in Table 3. Basing on the above-mentioned principles, we have developed a technology for amelioration of re-salinized irrigated land with the use of reclaimer crops (elongated variety of couch grass "Solonchak", blue crossbreed alfalfa). For the development of irrigated lands affected by the re-salinization and rising ground water levels, it is necessary to take into account crops salt tolerance from the point of view of specific soil ameliorative conditions (particle size and salt composition, ground water table).

The water and salt balance characterizes certain hydrologic zone with its inherent natural drainage conditions and peculiarities of the structure of water and salt regimes. The irrigation regime on saline lands in the agrophytocenoses of phyto-ameliorant plants depends on thickness of the root layer of soil, climatic and weather conditions, ground water table and biological features of plants. According to the Kalmyk branch of VNIIGIM ${ }^{7,8,9,15,22}$, in Kalmykia, depending on climatic zones, obtaining the yield of $15 . . .20 \mathrm{t} / \mathrm{h}$ of hay requires $6 \ldots 10$ irrigations with the norm of $3,750 \ldots . .7,700 \mathrm{~m}^{3} / \mathrm{ha}$. The irrigation norms in the zones 
vary between 5,400...1,100 and 1,650...7,700 m³/ha (Table. 4).

The most sensitive to salinity is alfalfa in the first year of life. Weakened seedlings deprived of air due to dense soil crust experience significant discomfort, sometimes weaning of plants is observed. If the soil crust remains undestroyed with the small irrigation ( $\left.150 \mathrm{~m}^{3} / \mathrm{ha}\right)$, plants may die. Disturbing the soil crust with harrowing is dangerous because of the risk of mechanical damaging the seedlings and pulling them out of the soil. As the root system develops and strengthens, salt tolerance of alfalfa increases ${ }^{4,10}$, $12,14,22$. On the second and third years of life, when the content of water-soluble salts reaches $0.452 \ldots 0.564 \%$, it may ensure, in case of sufficient water supply and nutrients, 4 mowings, with the total yield of 6.3...12.4 t/ha of hay (Table 5). The results of correlation analysis showed that with increasing salt content in the main root zone of plants $(0-70 \mathrm{~cm})$ by $0.1 \%$ between 0.2 and $0.4 \%$, the yield decreased by $18 \ldots . .20 \%$. On strongly

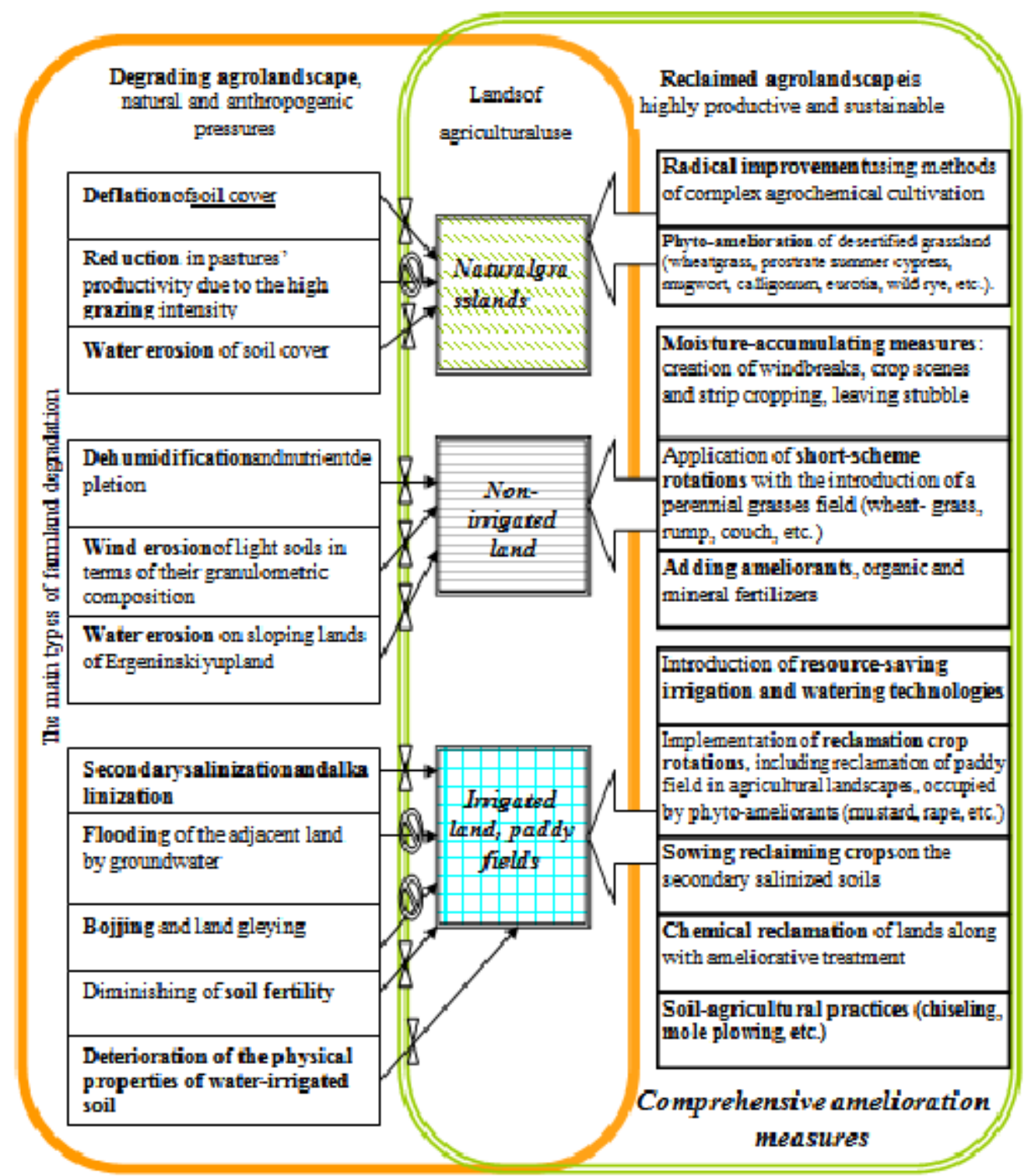

Fig. 1: Conceptual model of the natural resourcepotential growth of the degraded land by means of comprehensive amelioration; the type of degradation is excluded, $\mathrm{Z}$ - the type of degradation is controlled by means of comprehensive amelioration 
salinized (over $0.522 \%$ ) plots, loss of the yield was $70-80 \%$. It follows from here that on highly salinized soils with the content of water-soluble salts greater than $0.5 \%$, cultivation of alfalfa without prior reclamation activities (washing, chemical reclamation, etc.) is inefficient.

Intensity of plant growth not only depends on the content of salts in percent, but on the water supply for the crops as well. Correlation analysis shows that soil moisture has a strong direct positive effect on the production process $(\mathrm{r}=0.78)$ as well as indirect effect through reduced concentration of salts. The yield of elongated couchgrass hay in the $2 \mathrm{~d}$ and $3 r d$ years of life varies between 2.5 and $15.2 \mathrm{t} / \mathrm{ha}$, depending on the degree of soil salinity. If the content of water-soluble salts in the soil is more than 1.2-1.3\%, the yield of saltmarsh bluegrass reduces by $50-70 \%$. Therefore, taking care of agrocenoses of alfalfa and saltmarsh bluegrass should include: post emergence harrowing, which allows not only to destroy weeds, but to create required density of planting as well; repeated weeds mowing in the first year of crops' life (especially the "Solonchak" couchgrass); in the second and consequent years - performing early-spring dick harrowing, cultivation, plowing with chisel cultivators and autumn para-ploughing across rows after each $0.8 \ldots 1.0 \mathrm{~m}$ to the depth of $0.3 \ldots 0.4 \mathrm{~m}$ (width of the slits should be $0.04 \ldots 0.05 \mathrm{~m}$ ) in order to increase the rate of salts leaching from the root zone; maintaining optimal water regime in the root layer of the soil at the level of $75-80 \%$ of the field moisture capacity, which contributes to creation of descending water currents, removing salts from the root zone, and preventing their restoration in the intervals between irrigations. After mowing, the crops of couchgrass and alfalfa are treated with a disc harrow BIG-3 or BDT-2.2. This makes it possible to destroy some pests and to improve aeration of the top soil layer, to destroy the capillary fringe, and thus to reduce evaporation from the surface of crops. Under the influence of the activities recommended by the technologies of cultivating of phyto-ameliorants on strongly salinized soils, maintaining specified irrigation regime should be accompanied by leaching ions of chlorine, sodium, sulfates from the one meter layer of soil into deeper horizons ${ }^{11,13,18}$. As shown by the field studies, within three years of cultivation, irrigation of phyto ameliorants causes significant desalination of the one meter horizon: on the crops of blue-crossbred alfalfa - by $31 . . .46 \%$, in the crops of the Solonchak" couch grass - by $27 . . .35 \%$. During the growing season in the one meter layer of soil the content of the most dangerous and most mobile chloride ion decreases by $50-67 \%$, and redistribution of ion-sulfates from underlying horizons into the higher layers occurs.

\section{CONCLUSION}

We have substantiated and developed a conceptual model for enhancing productivity of degraded lands, the parameters and environmental constraints for water-salt regime of irrigated agricultural landscapes with comprehensive land amelioration in the semidesert and the desert-andsemidesert areas of Kalmykia. Based on the principles mentioned above, we have developed a technology of preventing degradation of agricultural land, and recovery of re-salinized irrigated lands with the use of reclaimer crops (elongated variety of couch grass "Solonchak", blue cross-breed alfalfa). Phyto-ameliorants have a great positive influence on agrochemical and agrophysical properties of soil. During the years of cultivating alfalfa and couch grass, 5.1...2.8 t/ha of organic matter accumulates in the soil with mowing and root residues, which, calculated as nutrients, makes $35 . . .87 \mathrm{~kg}$ of nitrogen, $8 . . .15 \mathrm{~kg}$ of $\mathrm{P}_{2} \mathrm{O}_{5}, 26 \ldots 45 \mathrm{~kg}$ of $\mathrm{K}_{2} \mathrm{O}$. In cultivating these crops, performing the main and inter-row cultivation contributes to softening, loosening of soil, which results in reducing density of the topsoil from 1.30 to $1.15 \mathrm{~g} / \mathrm{cm}^{3}$ and increasing total porosity from $42 \%$ to $46 \%$. Thus, cultivation of phyto-ameliorants on the re-salinized lands allows not only to recultivate soils that are dysfunctional due to resalinization, but to obtain additional high-quality forage as well.

This article has been prepared within the State Assignment of the Ministry of Education and Science "Ecological and landscape adaptive land use, biological and ameliorative methods of cultivating low-productive zonal types of soils in dry steppes and semi-deserts in production of highly profitable crop production” (the Kalmyk State University, project code No. 2726). 


\section{REFERENCES}

1. Averyanov, S.F., Salinity control of irrigated land Moscow, 1978; 288.

2. Kovda, V.A., The problems of desertification and salinity control of irrigated land Moscow.1984; 304.

3. Okonov, M.M., Irrigated lands of Kalmykia Elista: ed. APE “Jangar”, 1997; 71.

4. Parfenova, N.I., \& Reshetkina, N.M., Environmental principles of regulating hydrogeochemical regime of irrigated land (pp. 359). Shumakov, B.B. (Ed.). St Petersburg: Gidrometeoizdat, 1995.

5. Prihodko, V.E., Irrigated steppe soils: functioning, ecology, productivity, Moscow. 1996; 179.

6. Aidarov, I.P., \& Golovanov, A.I., Ameliorative regime of irrigated lands and ways to improve it. Hydraulic Engineering and Amelioration, 1986; 8: 44-47.

7. Bezdina, S.Y., Optimal parameters of ameliorative regime of soils. Hydraulic Engineering and Amelioration, 1986; 11: 58-63.

8. Kostyakov, A.N., The basics of amelioration Moscow: Selkhozgiz, 1960; 622.

9. Methodological guidelines for assessment criteria of the ameliorative condition of irrigated lands in the Volga region. Saratov: NGO "VolzhNIIGiM", 1991; 46.

10. Kovda, V.A., \& Sabolch, I. (Eds.)., Modeling the processes of salinization and alkalinization of soils Moscow: Nauka, 1980; 262.

11. Dedova, E.V., Borodychev, V.V., \& Okonov, M.M., Comprehensive amelioration As A Main Measure To Reclame Degraded Lands Of Kalmykia And To Increase Their Natural Resource Potential. American-Eurasian Journal of Sustainable Agriculture, 12014; -7.

12. Aidarov, I.P., Optimization of ameliorative modes of irrigated and drained agricultural lands (Recommendations). Moscow: VO
“Agropromizdat”, 1990; 58.

13. Dedova, E.B., Adyaev, S.B., \& Sazanov, M.A. Agrobiological features and technology of cultivating saltmarsh bluegrass in the desert zone of the Republic of Kalmykia. Proceedings of the International Scientific-Practical Conference on Preventing Desertification, Abakan. 2006; 158-162.

14. Belosludtceva, G.V., Yashin, V.M., \& Dedova, E.B., Substantiation of water-salt regime of brown semi-desert soils in Kalmykia on the basis of using the SWAP model. Amelioration and environment. The anniversary collection of scientific works. Moscow, 2004; 202-210.

15. Okonov, M.M., Kirpo, N.I., \& Dudakov, N.K. Regulating water and salt regime of soils in the Lower Volga region with irrigation: handbook . The Kalmyk University. Elista, 2003; 76.

16. Kizyaeva, B.M. (Ed.)., The regimes of comprehensive ameliorations (Recommendations). Moscow: RAAS, 2000; 63.

17. Bakinova, T.I., \& Zelenskaya, E.A., Degraded lands in Western zone of Kalmykia and measures for restoring their fertility. Elista, 1998; 109.

18. Zymovets, B.A. et al., Environmental requirements for irrigation of soils in Russia: Recommendations. Moscow: Soil. in-t n.a. V. V. Dokuchaev, 1996; 72.

19. Yashin, V.M., Dedova, E.B., \& Belosludtheva, V.G., Water and saline management in semi-arid zone of Kalmykia. Research on irrigation and drainage. Republic of Macedonia, 2004; 113121.

20. Agroclimatic resources of the Kalmyk ASSR Leningrad: Gidrometeoizdat, 1974, pp. 172.

21. Unkanzhinov, G. D. (Ed.), Agrochemical reported of the Republic of Kalmykia. Elista, 2013; 73.

22. Dedova, A.A., Saline lands phytomelioration in Kalmykia. Assembler of scientists articles, $M A B$ UNESCO. Paris, 2004; 131-137. 